\title{
136 PEDAGÓGICA
}

Asesinado

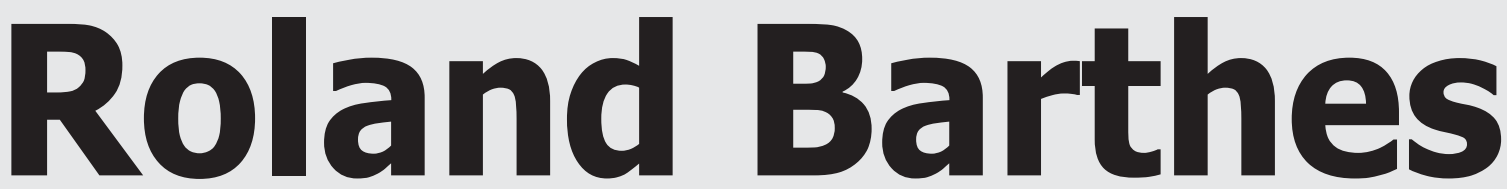

\section{La redacción}

Recientemente, los cables internacionales informaron acerca de la trágica muerte de Roland Barthes, el prestigioso semiólogo francés, acaecida a raíz de las múltiples fracturas que recibió al ser atropellado por un auto en una céntrica calle de París. «Lamentable accidente», han declarado unánimemente sus numerosos lectores.

Pero en realidad Roland Barthes fue asesinado. Y los autores intelectuales y materiales de este asesinato no son otros que los signos, confabulados contra el semiólogo a raíz de las denuncias que desde hace varios años venía haciendo de sus funciones mistificadoras y de dominación. «El lenguaje es una legislación —había escrito Barthes-, la lengua es su código. No vemos el poder que está en la lengua, pues olvidamos que toda lengua es una clasificación, y que toda clasificación es opresiva. Jakobson ha mostrado que un idioma se define menos por lo que permite decir que por lo que obliga a decir. De esta manera, 
por su estructura misma, la lengua implica una relación fatal de alienación. Hablar, y con mayor razón todavía discurrir, no es comunicar, como suele repetírselo de común y corriente, es someter: toda lengua es un sometimiento generalizado.

Obra del artista argentino León Ferrari / Museo de Arte del Banco de la República. Retrospectiva.

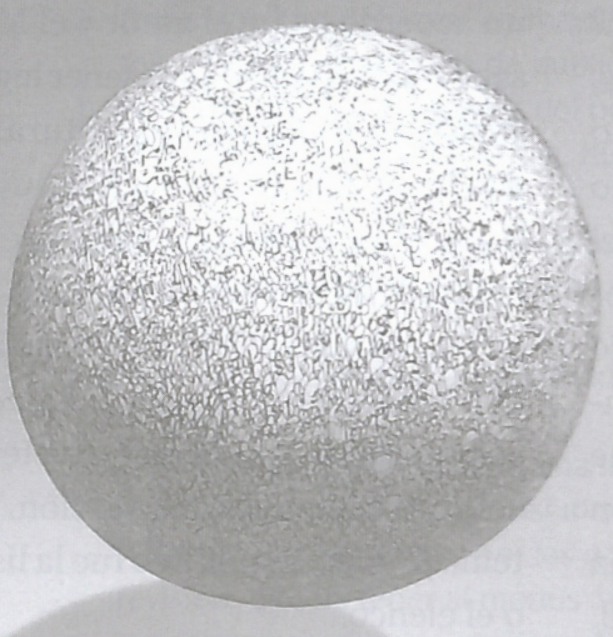

Desde el instante en que es proferida, así sea en la intimidad más profunda del sujeto, la lengua entra al servicio de un poder».

Anteriormente al que cegó su vida, Barthes había sido víctima de otros atentados llevados a cabo por los signos. En una ocasión estuvo a panto de morir asfixiado mientras ingería una sopa de letras. En otra, un estante repleto de libros de segunda casi lo aplasta. La terrible profusión de mala literatura que diariamente le llegaba no tenía otra finalidad que matarlo por contaminación ambiental. Pero finalmente los signos lograron su propósito mediante un sencillo pero ingenioso plan. Barthes empezó a cruzar la calle confiado en la luz verde del semáforo peatonal y en el carácter binario de dicho código, pero no se dio cuenta que, al mismo tiempo, el semáforo le daba luz verde al tránsito automotor. Las funestas consecuencias ya las conocemos.

Finalmente, este cínico asesinato debe poner en alerta a los otros semiólogos, y en especial a Umberto Eco, Julia Kristeva y Tzvetan Todorov.

Ekuóreo: un capítulo del minicuento en Colombia 2008. Universidad Pedagógica Nacional. Páginas 32-33. 